\title{
Pro- and Antioxidant Activity in the Blood of Adolescents of Different Ethnic Groups
}

\author{
${ }^{1}$ Scientific Centre for Family Health and Human Reproduction Problems \\ (ul. Timiryazeva 16, Irkutsk 664003, Russian Federation) \\ ${ }_{2}^{2}$ Pedagogical Institute, Irkutsk State University \\ (ul. Nizhnyaya Naberezhnaya 6, Irkutsk 664003, Russian Federation)
}

\begin{abstract}
Background. Processes of antioxidant protection in different ethnicities, living in the same geographical conditions, are of undoubted scientific interest. The ratio of activity of oxidative processes and antioxidant components not only reflects, but also largely determines the metabolism and adaptive capabilities of the organism. The key issue in understanding the regulatory and adaptive role of lipid peroxidation reactions in the body is the idea of the existence of a certain balance with the antioxidant defense system.

Aims: to study the features of the system of lipid peroxidation and antioxidant protection in adolescents of different ethnicities, living in Eastern Siberia.

Materials and methods. Parameters of lipid peroxidation and antioxidant protection were determined in the blood serum by spectrophotometric methods.

Results. We found that adolescent Buryat boys had statistically significant decrease in primary and secondary products of lipid peroxidation: ketodienes and conjugated trienes, malondialdehyde, and components of antioxidant protection: retinol, $\alpha$-tocopherol, the level of total antioxidant activity of blood and reduced glutathione, in comparison with Caucasian adolescents. In Caucasian adolescents with endocrine disorders, there was a statistically significant increase in the level of ketodienes and conjugated trienes, as well as the activity of superoxide dismutase against the background of a decrease of reduced glutathione, tocopherol, and retinol. We revealed a significant increase in the concentration of ketodienes and conjugated trienes and a decrease of the oxidized glutathione in adolescents with endocrine disorders in comparison with healthy adolescents of Buryat ethnicity.

Conclusions. Studying of the processes of lipid peroxidation and antioxidant system of the organism can be used as an additional criterion for complex examination of practically healthy adolescents, which significantly enhance the representation about the adaptation possibilities of the organism to external conditions and can become a basis for effective examination of reproductive health in the future.
\end{abstract}

Key words: adolescents, reproductive health, lipoperoxidation, antioxidants

For citation: Kurashova N.A., Kudeyarova E.A. Pro- and antioxidant activity in the blood of adolescents of different ethnic groups. Acta biomedica scientifica, 2018, 3 (6), 23-28, DOI 10.29413/ABS.2018-3.6.3.

\section{Про- и антиоксидантная активность крови у подростков разных этнических групп}

\author{
Курашова Н.А. ', Кудеярова Е.А. ${ }^{2}$ \\ 1 ФГБНУ “Научный центр проблем здоровья семьи и репродукции человека» \\ (664003, г. Иркутск, ул. Тимирязева, 16, Россия) \\ 2 Педагогический институт, ФГБОУ ВО “Иркутский государственный университет»
} (664003, г. Иркутск, ул. Нижняя Набережная, 6, Россия)

\section{Резюме}

Обоснование. В исследовании представлен сравнительный анализ параметров липопероксидации и антиоксидантной защиты у мальчиков подросткового возраста различных этнических групп Восточной Сибири. Соотношение активности окислительных процессов и антиоксидантных компонентов не только отражает, но и во многом определяет интенсивность метаболизма и адаптационных возможностей организма подростков русской и бурятской популящий.

Цель исследования: выявить особенности системы перекисного окисления липидов и антиоксидантной защиты у подростков разных этнических групп, проживающих в Восточной Сибири.

Методы. Подросткам проведено стандартное клинико-лабораторное обследование и осуществлён осмотр эндокринологом-андрологом. В качестве материала для биохимических исследований использовали сыворотку крови и гемолизат. Конщентрацию продуктов перекисного окисления липидов, общую антиокислительную активность крови и её компонентов определяли на спектрофлуорофотометре «SHIMADZU-1501» (Япония). При анализе межгрупповых различий для независимых выборок использовали параметрический t-критерий Стьюдента.

Результаты. Обследовано 55 мальчиков бурятской популяции (26 мальчиков с эндокринными нарушениями, 29 практически здоровых подростков) и 81 мальчик русской популяции (46 мальчиков с эндокринными нарушениями, 35 практически здоровых подростков) в возрасте 14-17 лет. У практически здоровых подростков бурятской популяции выявлено статистически значимое снижение первичных и конечных продуктов липопероксидации, а также компонентов антиоксидантной защиты (конщентраций ретинола, $\alpha$-токоферола, уровня общей антиокислительной активности крови и восстановленного глутатиона) на фоне повышенной активности супероксиддисмутазы, в сравнении с подростками русской популяции. У подростков бурятского этноса с эндокринными нарушениями, в сравнении с практически здоровыми подростками, выявлено значимое повышение концентрации вторичных липоперекисных продуктов и 
снижение уровня окисленного глутатиона. У русских подростков с эндокринными нарушениями установлено значимое повышение уровня первичных продуктов, а также активности супероксиддисмутазы на фоне снижения концентрации восстановленного глутатиона и жирорастворимых антиоксидантов по сравнению с практически здоровыми мальчиками.

Заключение. Ключевым вопросом в понимании регуляторной и адаптивной роли реакций перекисного окисления липидов в организме является представление о существовании определённого баланса с системой антиоксидантной защиты. Установленные особенности процессов перекисного окисления липидов и антиоксидантной защиты у мальчиков подросткового возраста разных этнических групп характеризуют разную степень активности метаболических процессов и могут быть обусловлены этнической принадлежностью.

Ключевые слова: подростки, репродуктивное здоровье, липопероксидация, антиоксиданты

Для цитирования: Курашова Н.А., Кудеярова Е.А. Про- и антиоксидантная активность крови у подростков разных этнических групп. Acta biomedica scientifica, 2018, 3 (6), 23-28, DOI 10.29413/ ABS.2018-3.6.3.

In the process of evolution, organisms learned how to convert molecular oxygen to energy, however, Joseph Priestley and Antoine Lavoisier first thought that oxygen can be not only a source of life, but also act as its destroyer. In 1959, Rebekko Geshman substantiated the molecular mechanisms of the toxic effects of oxygen, by studying the generation of active oxygen species (ROS), also called free radicals. At present time, the influence of free radicals on the development of oxidative stress in cells, organs and the human body has been proved [10]. ROS are oxidants and therefore they are highly toxic for all types of biomolecules - lipids, DNA, proteins and carbohydrates [1].

Anthropogenic environmental factors have a significant impact on formation of population health $[3,9,15]$. In recent years, there are more and more dangerous areas, individual zones of an unfavorable ecological situation. The reaction of the body to anthropogenic impact depends on sex, age, individual characteristics and the state of human health $[11,12,19]$. Children and patients with chronic diseases are more vulnerable. According to many authors, environmental factors in 18-20\% determine the state of health and are in second place after the way of life $[5,17,21]$. It should be noted that the health status of children is an indicator of the degree of environmental hazards due to the high sensitivity of the organism, the morphofunctional immaturity of the adaptation system and the metabolic status $[6,10,11]$.

Adolescence is an important period of growth and development of the whole organism [2, 3, 21]. A special feature of the adolescent period is an increase in the transition of acute forms of diseases to recurrent and chronic diseases, as well as an increase in the primary chronic pathology of internal organs $[8,20]$.

The study of the peculiarities of lipoperoxidation processes and components of antioxidant protection in people of different ethnic populations living in the same geographical conditions is of undoubted scientific interest $[13,14,16,22]$. The key issue in understanding the regulatory and adaptive role of lipid peroxidation reactions in the body is the idea of the existence of a certain balance with the antioxidant defense system.

The purpose of this study was to identify the characteristics of the lipid peroxidation system and antioxidant protection in adolescents of different ethnicities, living in Eastern Siberia.

\section{MATERIALS AND METHODS OF RESEARCH}

In the course of the work, 55 adolescent boys of Buryat population ( 26 boys with endocrine disorders, 29 - practically healthy adolescents) and 81 adolescent boys of Russian population (46 boys with endocrine disorders, 35 - practically healthy adolescents) aged 14-17 (mean age $15.09 \pm 0.08$ years). All teenagers live in Bayandai village of the Ust-Orda national district of the Irkutsk region. Patients underwent a standard clinical and laboratory examination. An endocrinologist examined them all. The main groups of the study included adolescents, diagnosed with endocrine disorders, such as delayed sexual development, hypothalamic syndrome of puberty, diffuse non-toxic goiter. The exclusion criterion was obesity. Ethnicity was determined taking into account the phenotypic characteristics of the child and the data of the genealogical history (children having two generations of parents of the same ethnic group). Adolescents of the ethnic groups under study did not differ in age, social status, family income level, provision of medical assistance, and nutrition. The materials of the study were serum and hemolysate. Blood sampling was carried out from the ulnar vein in accordance with generally accepted requirements. We followed ethical principles of the Helsinki Declaration of the World Medical Association (World Medical Association Declaration of Helsinki, 2013). The intensity of lipid peroxidation (LPO) in the blood was assessed by the content of its products - diene conjugates (DC), ketodienes and conjugated trienes (KD-ST), malondialdehyde by the method of V. Gavrilova et al. (1983), determined by the fluorimetric method of V. Gavrilova (1987). The antioxidant protection system was assessed according to the following parameters: total anti-oxidant activity (AOA) of blood - by the method of G. Klebanova (1988), the level of $\alpha$-tocopherol and retinol - by the method of R. Chernyauskene et al. (1984), the content of reduced and oxidized glutathione (GSH and GSSG) - by the method of P.J. Hisin, R. Hilf (1976), the activity of superoxide dismutase (SOD) - by method of H.P. Misra, I. Fridovich (1972). Shimadzu RF1501 spectrophotometer (Japan) was used.

Statistical analysis of data was carried out using Statistica 6.1 (StatSoft Inc., USA; license holder - Scientific Centre for Family Health and Human Reproduction Problems). The type of distribution was established by the Kolmogorov - Smirnov criterion. To assess the statistically significant differences in the obtained data, the Student's 
test was used. Differences were considered statistically significant at $p<0.05$.

\section{RESULTS AND DISCUSSION}

As a result of the study, we found a statistically significant decrease in lipid peroxidation primary and secondary products: KD-CT (ketodienes and conjugated trienes), MDA (malondialdehyde) and antioxidant protection components: concentrations of retinol, $\alpha$-tocopherol, total blood AOA and GSH in comparison with adolescents of the Caucasian population (Fig. 1). The activity of SOD (superoxide dismutase) is significantly higher among adolescents of the Buryat ethnic group. Enzymatic systems play a major role in regulating the LPO (lipid peroxidation) processes at the stage of initiation of lipid peroxidation. Being a key link in the system of regulation of the stationary concentration of superoxide radicals, SOD performs not only a protective function, but also a regulatory function. Reduction of the reduced form of glutathione, which acts as a hydrogen donor and a cofactor of a number of antioxidant enzyme systems, characterizes the weakening of the resistance of cells and the organism in all healthy Buryat adolescents. Retinol penetrates into the hydrophobic zone of biomembranes and interacts with lecithin-cholesterol monolayers at the phase interface, causing the restructuring of cell membranes, lysosomes and mitochondria [18]. The low concentration of tocopherol and retinol in adolescents in the Buryat population is probably associated with national eating behavior [4]. The decrease in AOS among adolescents of the Buryat ethnic group is an unfavorable factor for the organism, since further oxidative stress can lead to a sharp induction of reactive oxygen species not compensated by the components of the antioxidant system.

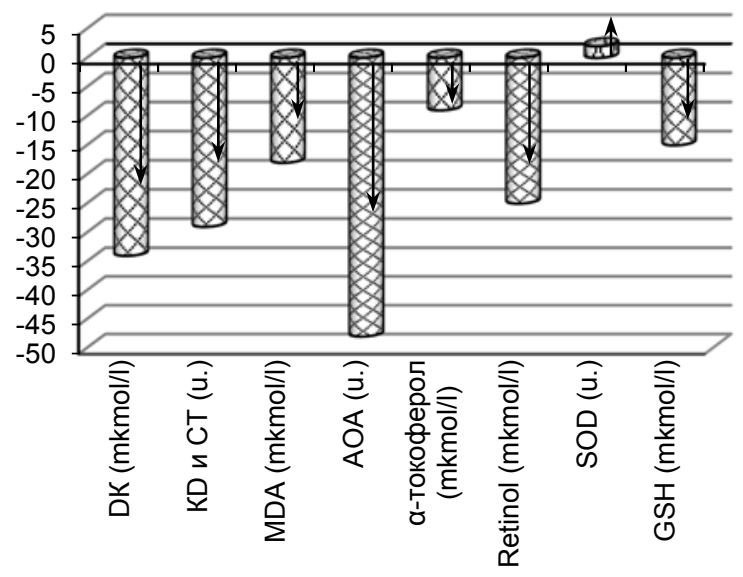

Fig. 1. Change in indicators of LPO-AOS processes in practically healthy adolescents of Caucasian and Buryat populations: $0 \%$ - the level of indicators of the LPO-AOS system in the blood of practically healthy adolescents of the Caucasian population.

As a result of comparing the indicators of the LPO-AOS system in Russian adolescents with endocrine disorders, a statistically significant increase in the level of KD-CT, as well as the activity of SOD, was observed against the background of a decrease in the concentration of GSH and fat-soluble antioxidants tocopherol and retinol, compared to practically healthy boys (Fig. 2) The adolescence is characterized by a lack of adaptive mechanisms, and elevated susceptibility to environmental factors [3]. Reduction of bio-antioxidants of retinol and $\alpha$-tocopherol is associated with their consumption for inactivation of LPO products. The role of retinol in the adolescence is very important in connection with its participation in the synthesis of steroid hormones. There is evidence of a direct relationship between the content of sex steroids and gonadotropins in the blood from the retinol concentration, as well as the delay in sexual development in children with a deficiency of retinol $[4,11]$. The main antioxidant effect of glutathione is realized through its participation in the work of enzymatic antioxidants. In adolescents with endocrine disorders there is probably a decrease in the activity of other components of the glutathione system, in particular, glutathione reductase, the purpose of which is to maintain a high level of GSH.

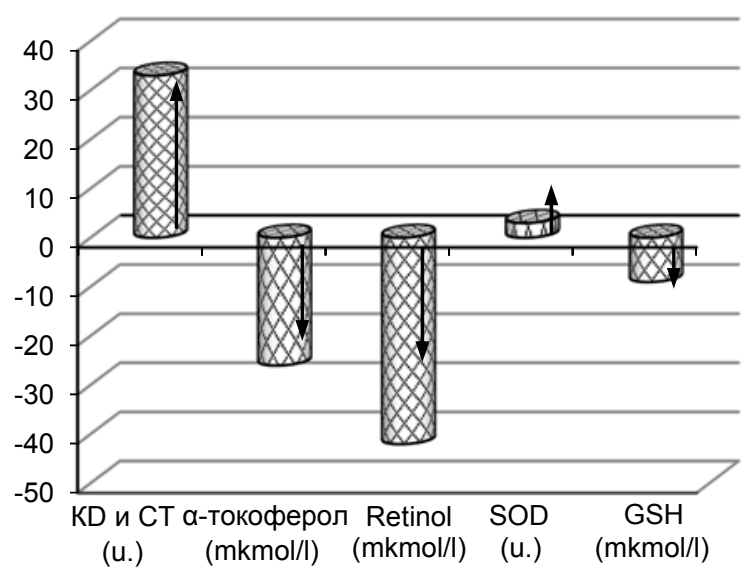

Fig. 2. Changes in the indicators of LPO-AOS processes in adolescents with endocrine disorders of the Caucasian population: $0 \%$ - the level of indicators of the LPO-AOS system in the blood of practically healthy adolescents of the Caucasian population.

We found a significant increase in the concentration of secondary lipoperoxides products of KD-CT and a decrease in the level of GSSG (fig. 3) as a result of studying the processes of LPO-AOS in Buryat adolescents with endocrine disorders in comparison with practically healthy adolescents.

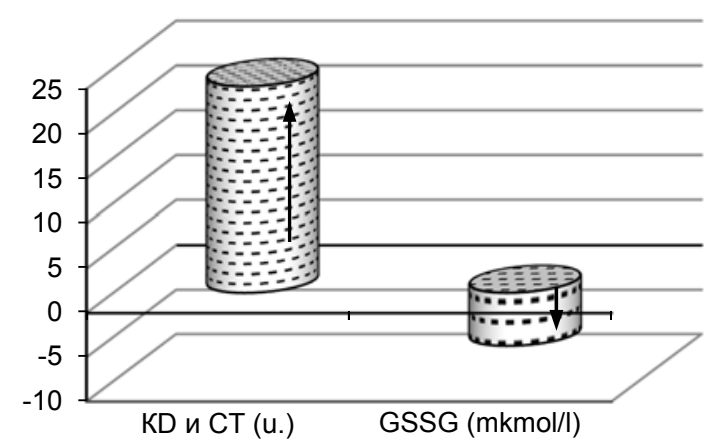

Fig. 3. Changes of the indicators LPO-AOS processes in adolescents with endocrine disorders of the Buryat population: $0 \%$ - the level of indicators of the LPO-AOS system in the blood of practically healthy adolescents of the Buryat population. 
Accumulation of products, formed at intermediate stages of peroxidation processes can provoke a multilateral damaging effect on many biopolymers and cellular structures [4]. A significant increase in only one LPO product is a sufficient criterion for the activation of a multistage free-radical mechanism [4]. Violation of at least one of the links of antioxidant protection leads to the launch of radical oxidation chain reaction and the shift of the equilibrium system to the prooxidant side with the development of pathological manifestations. Reduction of oxidized glutathione serves the reflection of the imbalance of the glutathione cell protection system against free radical damage and may be a consequence of endocrine disorders in Buryat adolescents. The recovery of GSSG is due to glutathione reductase, which activity is probably reduced in adolescents with endocrine disorders of the Buryat population [4]. To sum it all up, in adolescents of the Buryat ethnos with endocrine disorders, the compensatory capacities of the antioxidant system are depleted, as evidenced by a decrease in the activity of the enzymatic link.

\section{CONCLUSION}

Physiological adaptation is a defensive reaction of a healthy organism, which at the same time can pass into a pathophysiological reaction. If the acting factor was not very intense or short-lived, the body retains a satisfactory adaptation. However, with a strong impact or its long duration, tension or disruption of regulatory systems occurs. Numerous researches show that data on an ethnic origin can give additional information for the personified approach in treatment $[4,10,11,13]$. The specific features of lipid peroxidation and antioxidant protection characterize the activity of metabolic processes of adolescent boys of different ethnic groups and can be determined by ethnicity. Determination of the key parameters of lipid peroxidation and antioxidant protection is extremely important for the prevention and correction of pathological manifestations of oxidative stress, as an etiological factor in the development of a wide range of diseases.

\section{ЛИТЕРАТУРА.}

1. Агаева С.Э., Алибекова С.С. О взаимосвязи между физической нагрузкой, окислительным стрессом и иммунной реакцией // Университетский спорт: здоровье и процветание нации: Материалы V Международной научной конференции студентов и молодыхученых (Казань, 23-24 апр. 2015 г.). - Казань, 2015. - С. 121-123.

2. Баранов А.А., Намазова-Баранова Л.С., Ильин А.Г. Сохранение и укрепление здоровья подростков - залог стабильного развития общества и государства (состояние проблемы) // Вестник Российской академии медицинских наук. - 2014. - Т. 69, № 5-6. - C. 65-70. - doi: 10.15690/vramn.v69i5-6.1046

3. Загарских Е.Ю. Медико-социальные аспекты формирования нарушений репродуктивного потенциала у мальчиков подросткового возраста, проживающих в промышленных центрах // Международный эндокринологический журнал. - 2011. № 1. - С. 108-117.
4. Колесникова Л.И., Даренская М.А., Гребенкина Л.А., Сутурина Л.В., Лабыгина А.В., Семенова Н.В., Цыренов Т.Б., Даржаев 3.Ю., Курашова Н.А., Толпыгина О.А. Особенности состояния антиоксидантной системы у здоровых лиц основных этнических групп Прибайкалья // Вопросы питания. - 2012. - Т. 81, № 3. - С. 46-51.

5. Павлова А.Н., Макарова В.И. Состояние здоровья подростков, проживающих в экологически неблагополучном районе // Medicus. - 2015. - № 3. С. 44-47.

6. Пешкова И.А. Факторы, влияющие на репродуктивное здоровье детей // Успехи современного естествознания. - 2007. - № 6. - С. 89-91.

7. Ходос М.Я., Казаков Я.Е., Видревич М.Б., Брайнина Х.З. Окислительный стресс и его роль в патогенезе // Вестник Уральской медицинской академической науки. - 2017. - Т. 4, № 4. - С. 381-398. - doi: 10.22138/2500-0918-2017-14-4-381-398.

8. Яйленко А.А. Проблемы подросткового возраста // Смоленский медицинский альманах. - 2016. № 4. - С. 198-206.

9. Blumberg JB, Frei B, Fulgoni VL, Weaver CM, Zeisel SH. (2017). Contribution of dietary supplements to nutritional adequacy in race/ethnic population subgroups in the United States. Nutrients, 9 (12). pii: E1295. doi: 10.3390/nu9121295.

10. Darenskaya MA, Gavrilova OA, Rychkova LV, Kravtsova OV, Grebenkina LA, Osipova EV, Kolesnikov SI, Kolesnikova LI. (2018). The assessment of oxidative stress intensity in adolescents with obesity by the integral index. Int J Biomed, 8(1), 37-41. doi: 10.21103/Article8(1)_OA5

11. Darenskaya MA, Kolesnikov SI, Rychkova LV, Grebenkina LA, Kolesnikova LI. (2018). Oxidative stress and antioxidant defense parameters in different diseases: ethnic aspects. Free Rad Biol Med, 120 (S1), 60. doi: 10.1016/j.freeradbiomed.2018.04.199

12. Darenskaya MA, Rychkova LV, Kolesnikov SI, Gavrilova OA, Kravtsova OV, Grebenkina LA, Kolesnikova LI. (2017). Oxidative stress parameters in adolescent boys with exogenous-constitutional obesity. Free Radic Biol Med, 112, 129-130. doi: 10.1016/j.freeradbiomed.2017.10.195.

13. Eldeirawi K, Koenig MD, Persky V, Chavez N. (2014). Nativity and serum concentrations of antioxidants in Mexican American children: a cross-sectional study. Nutrients, 6 (4), 1598-1607. doi: 10.3390/nu6041598.

14. Hiragi CO, Miranda-Vilela AL, Rocha DM, de Oliveira SF, Hatagima A, de Nazaré Klautau-Guimarães M. (2011). Superoxide dismutase, catalase, glutathione peroxidase and gluthatione S-transferases M1 and T1 gene polymorphisms in three Brazilian population groups. Genet Mol Biol, 34 (1), 11-18. doi: 10.1590/S141547572010005000102 .

15. Jackson DB, Beaver KM. (2015). The role of adolescent nutrition and physical activity in the prediction of verbal intelligence during early adulthood: a genetically informed analysis of twin pairs. Int J Environ Res Public Health, 12 (1), 385-401. doi: org/10.3390/ ijerph120100385.

16. Karban A, Krivoy N, Elkin H, Adler L, Chowers Y, Eliakim R, Efrati E. (2011). Non-Jewish Israeli IBD pa- 
tients have significantly higher glutathione S-transferase GSTT1-null frequency. Dig Dis Sci, 56 (7), 2081-2087. doi: 10.1007/s10620-010-1543-4.

17. Kim JA, Choi HM, Seo Y, Kang DR. (2018) Relations among obesity, family socioeconomic status, oral health behaviors, and dental caries in adolescents: the 2010-2012 Korea National Health and nutrition examination survey. BMC Oral Health, 18 (1), 114. doi: 10.1186/ s12903-018-0576-5.

18. Laitinen TT, Nuotio J, Juonala M, Niinikoski H, Rovio S, Viikari JSA, Rönnemaa T, Magnussen CG, Jokinen E, Lagström H, Jula A, Simell O, Raitakari OT, Pahkala K. (2018). Success in achieving the targets of the 20-year infancy-onset dietary intervention: association with insulin sensitivity and serum lipids. Diabetes Care, dc180869. doi: 10.2337/dc18-0869.

19. Madaeva IM, Berdina ON, Mandzyak T, Kolesnikov SI, Kolesnikova LI. (2016). Sleep patterns in adolescents with hypertension. Int J Biomed, 6 (1), 53-55. doi: 10.21103/Article6(1)_0A11.

20. Mayer-Davis EJ, Maahs DM, Seid M, Crandell J, Bishop FK, Driscoll KA, Hunter CM, Kichler JC, Standiford D, Thomas JM. (2018). Efficacy of the Flexible Lifestyles Empowering Change intervention on metabolic and psychosocial outcomes in adolescents with type 1 diabetes (FLEX): a randomised controlled trial. Lancet Child Adolescent Health, 2 (9): 635-646. doi: 10.1016/ S2352-4642(18)30208-6.

21. Shahsanai A, Farajzadegan Z, Hadisichani Z, Heidari K, Omidi R. (2018). Assessment of the relationship between nutritional knowledge and anthropometric indices in Isfahan children and adolescent. Adv Biomed Res, 7, 110. doi: 10.4103/abr.abr_1_18.

22. Talegawkar SA, Johnson EJ, Carithers T, Taylor HA Jr, Bogle ML, Tucker KL. (2007). Total alpha-tocopherol intakes are associated with serum alpha-tocopherol concentrations in African American adults. J Nutr, 7 (10), 2297-303.

\section{REFERENCES}

1. Agaeva SE, Alibekova SS. (2015). On the relationship between exercise, oxidative stress and immune response [0 vzaimosvyazi mezhdu fizicheskoy nagruzkoy, okislitel'nym stressom i immunnoy reaktsiey]. Universitetskiy sport: zdorov'e i protsvetanie natsii: Materialy $\mathrm{V}$ Mezhdunarodnoy nauchnoy konferentsii studentov $i$ molodykh uchenykh. Kazan, 121-123. (In Russ.)

2. Baranov AA, Namazova-Baranova LS, Ilyin AG. (2014). Maintenance and health promotion of adolescent - basis of sustainable development of society and state (current status of the issue) [Sokhranenie i ukreplenie zdorov'ya podrostkov - zalog stabil'nogo razvitiya obshchestva i gosudarstva (sostoyanie problemy)]. Vestnik Rossiyskoy akademii meditsinskikh nauk, 69 (5-6), 65-70. doi: 10.15690/vramn.v69i5-6.1046. (In Russ.)

3. Zagarskih EYu. (2011). Medical and social aspects of formation of reproductive potential disorders in adolescent boys living in industrial centers [Mediko-sotsial'nye aspekty formirovaniya narusheniy reproduktivnogo potentsiala u mal'chikov podrostkovogo vozrasta, prozhivayushchikh v promyshlennykh tsentrakh]. Mezhdunarodnyy endokrinologicheskiy zhurnal, (1), 108-117. (In Russ.)
4. Kolesnikova LI, Darenskaya MA, Grebenkina LA, Suturina LV, Labygina AV, Semenova NV, Tsyrenov TB, Darzhaev ZYu, Kurashova NA, Tolpygina OA. (2012). State features of the antioxidant system in healthy people of the basic ethnic groups of Pribaikalye [Osobennosti sostoyaniya antioksidantnoy sistemy u zdorovykh lits osnovnykh etnicheskikh grupp Pribaykal'ya]. Voprosy pitaniya, 81 (3), 46-51. (In Russ.)

5. Pavlova AN, Makarova VI. (2015). Health status of adolescents living in an ecologically disadvantaged area [Sostoyanie zdorov'ya podrostkov, prozhivayushchikh v ekologicheski neblagopoluchnom rayone]. Medicus, (3), 44-47. (In Russ.)

6. Peshkova IA. (2007). Factors affecting the reproductive health of children [Faktory, vliyayushchie na reproduktivnoe zdorov'e detey]. Uspekhi sovremennogo estestvoznaniya, (6), 89-91. (In Russ.)

7. Khodos MYa, Kazakov YaE, Vidrevich MB, Brainina KhZ. (2017). Oxidative stress and its role in pathogenesis [Okislitel'nyy stress i ego rol' v patogeneze]. Vestnik Ural'skoy meditsinskoy akademicheskoy nauki, (4), 381-398. doi: 10.22138/2500-0918-2017-14-4-381-398 (In Russ.)

8. Yaylenko AA. (2016). Problems of adolescence [Problemy podrostkovogo vozrasta]. Smolenskiy meditsinskiy al'manakh, (4), 198-206.

9. Blumberg JB, Frei B, Fulgoni VL, Weaver CM, Zeisel SH. (2017). Contribution of dietary supplements to nutritional adequacy in race/ethnic population subgroups in the United States. Nutrients, 9 (12). pii: E1295. doi: 10.3390/nu9121295.

10. Darenskaya MA, Gavrilova OA, Rychkova LV, Kravtsova OV, Grebenkina LA, Osipova EV, Kolesnikov SI, Kolesnikova LI. (2018). The assessment of oxidative stress intensity in adolescents with obesity by the integral index. Int J Biomed, 8 (1), 37-41. doi: 10.21103/ Article8(1)_0A5

11. Darenskaya MA, Kolesnikov SI, Rychkova LV, Grebenkina LA, Kolesnikova LI. (2018). Oxidative stress and antioxidant defense parameters in different diseases: ethnic aspects. Free Rad Biol Med, 120 (S1), 60. doi: 10.1016/j.freeradbiomed.2018.04.199

12. Darenskaya MA, Rychkova LV, Kolesnikov SI, Gavrilova OA, Kravtsova OV, Grebenkina LA, Kolesnikova LI. (2017). Oxidative stress parameters in adolescent boys with exogenous-constitutional obesity. Free Radic Biol Med,112, 129-130. doi: 10.1016/j.freeradbiomed.2017.10.195.

13. Eldeirawi K, Koenig MD, Persky V, Chavez N. (2014). Nativity and serum concentrations of antioxidants in Mexican American children: a cross-sectional study. Nutrients, 6 (4), 1598-1607. doi: 10.3390/ nu6041598.

14. Hiragi CO, Miranda-Vilela AL, Rocha DM, de Oliveira SF, Hatagima A, de Nazaré Klautau-Guimarães M. (2011). Superoxide dismutase, catalase, glutathione peroxidase and gluthatione S-transferases M1 and $\mathrm{T} 1$ gene polymorphisms in three Brazilian population groups. Genet Mol Biol, 34 (1), 11-18. doi: 10.1590/S141547572010005000102.

15. Jackson DB, Beaver KM. (2015). The role of adolescent nutrition and physical activity in the pre- 
diction of verbal intelligence during early adulthood: a genetically informed analysis of twin pairs. Int J Environ Res Public Health, 12 (1), 385-401. doi: org/10.3390/ ijerph120100385.

16. Karban A, Krivoy N, Elkin H, Adler L, Chowers Y, Eliakim R, Efrati E. (2011). Non-Jewish Israeli IBD patients have significantly higher glutathione S-transferase GSTT1-null frequency. Dig Dis Sci, 56 (7), 2081-2087. doi: 10.1007/s10620-010-1543-4.

17. Kim JA, Choi HM, Seo Y, Kang DR. (2018) Relations among obesity, family socioeconomic status, oral health behaviors, and dental caries in adolescents: the 2010-2012 Korea National Health and nutrition examination survey. BMC Oral Health, 18 (1), 114. doi: 10.1186/ s12903-018-0576-5.

18. Laitinen TT, Nuotio J, Juonala M, Niinikoski H, Rovio S, Viikari JSA, Rönnemaa T, Magnussen CG, Jokinen E, Lagström H, Jula A, Simell O, Raitakari OT, Pahkala K. (2018). Success in achieving the targets of the 20-year infancy-onset dietary intervention: association with insulin sensitivity and serum lipids. Diabetes Care, dc180869. doi: 10.2337/dc18-0869.
19. Madaeva IM, Berdina ON, Mandzyak T, Kolesnikov SI, Kolesnikova LI. (2016). Sleep patterns in adolescents with hypertension. Int J Biomed, 6 (1), 53-55. doi: 10.21103/Article6(1)_OA11.

20. Mayer-Davis EJ, Maahs DM, Seid M, Crandell J, Bishop FK, Driscoll KA, Hunter CM, Kichler JC, Standiford D, Thomas JM. (2018). Efficacy of the Flexible Lifestyles Empowering Change intervention on metabolic and psychosocial outcomes in adolescents with type 1 diabetes (FLEX): a randomised controlled trial. Lancet Child Adolescent Health, 2 (9): 635-646. doi: 10.1016/ S2352-4642(18)30208-6.

21. Shahsanai A, Farajzadegan Z, Hadisichani Z, Heidari K, Omidi R. (2018). Assessment of the relationship between nutritional knowledge and anthropometric indices in Isfahan children and adolescent. Adv Biomed Res, 7, 110. doi: 10.4103/abr.abr_1_18.

22. Talegawkar SA, Johnson EJ, Carithers T, Taylor HA Jr, Bogle ML, Tucker KL. (2007). Total alpha-tocopherol intakes are associated with serum alpha-tocopherol concentrations in African American adults. J Nutr, 7 (10), 2297-303.

\section{Information about the authors}

Nadezhda A. Kurashova - Dr. Sc. (Biol.), Senior Research Officer at the Laboratory of Pathophysiology, Scientific Centre for Family Health and Human Reproduction Problems (664003, Irkutsk, ul. Timiryazeva, 16, tel. (3952) 20-73-67; e-mail: nakurashova@yandex. ru) ๑ http://orcid.org/0000-0001-8591-8619.

Ekaterina A. Kudeyarova - Student, Pedagogical Institute, Irkutsk State University (664003, Irkutsk, ul. Nizhnyaya Naberezhnaya, 6; e-mail: ekaterina.kudeyarova2015@yandex.ru) 